\title{
Evaluate Strength of Geopolymer Concrete by Using Oven Curing
}

\author{
Prof. P. K. Jamdade ${ }^{1}$, Prof. U. R. Kawade ${ }^{2}$ \\ ${ }^{I}$ Assistant Professor, Sahyadri Valley College of Engineering and Technology, Rajuri, Dist. Pune \\ ${ }^{2}$ Associate Professor, Padmashri Dr. Vitthalrao Vikhe Patil College of Engineering, Ahmednagar
}

\begin{abstract}
Around 120 million tone of fly ash get accumulated every year at the thermal power stations in India. Similarly aggregate crusher units produce enormous quantities of stone dust, a waste product, produced during crushing of rubble. Due to scarcity of land disposal becomes a serious problem. Because of the growing concern with environmental issues and increasing interest in conservation of energy and resources, every country has to face the challenging problem that how to use or dispose this by-product within the framework of its economic structure. Due to this the fly ash is used as ingredients in concrete which enhance the properties of concrete and utilization of fly ash is helpful for consumption. In this study the alkaline solution of sodium silicate and sodium hydroxide is mixed with processed fly ash to become geopolymer concrete. This concrete is cured at different condition and different temperature so as to increase the strength of concrete.
\end{abstract}

Keyword: Geopolymer Concrete, Processed Fly ash.

\section{Introduction}

Geopolymer concrete is a new material in which cement is totally replaced by the pozzolanic materials that is rich in Silicon $(\mathrm{Si})$ and Aluminium $(\mathrm{Al})$ like fly ash. It is being done by highly alkaline liquids to produce the binder which binds the aggregates in concrete when subjected to elevated temperature. Geopolymers were developed as a result of research into heat resistant materials after a series of calamitous fires. The experiment shows non-flammable and non-combustible geopolymer binders and resins (amber). Geopolymer has been studied and assures as a greener alternative to portland cement concrete. We have observed that the way of research is changing from chemistry domain to engineering applications and commercial production of geopolymer. After various experiments it has been found that geopolymer concrete has good engineering properties. The chemical process followed in this process is polymerization.

The polymerization process involving a chemical reaction between minerals that are rich in aluminumsilicon like fly ash. Each and every year production of portland cement is increasing with the increasing demand of construction. Therefore the rate of production of carbon dioxide released to the atmosphere is also increasing. Each ton of Portland cement releases a ton of $\mathrm{CO}_{2}$. The greenhouse gas emission from the production of portland cement is about 1.33 billion tons yearly, it means approximately $6.99 \%$ of the overall greenhouse gas discharge. Beside of this, fly ash is the ruin material of coal based thermal power plant, and it is having disposal problem. Most of the land is covered by thermal power plants for the distruction of fly ash. So fly ash creates health problems like asthma.

\section{Research Methodology}

The selection of materials and mix proportioning of Geopolymer Concrete is done to achieve objectives, namely adequate compressive strength. By avoiding the effect of unknown contaminants in the mixing water, the sodium hydroxide flakes were dissolves in distilled water, activator solution was prepared at least one day prior to its use. Use at least two type of locally available aggregates that is coarse aggregate and fine aggregate in saturated surface dry condition, As the fly ash gets finer the material gets better to be use.

\section{Properties Of Geopolymer Concrete}

The Properties Of Geopolymer Concrete, [S. E. Wallah And B. V. Rangan, 2006], Previous Studies Have Reported That Geopolymer Holds Sulfate Resistance, Corrosion Resistance, High Early Strength, Low Shrinkage, Freeze-Thaw Resistance, Acid Resistance, No Dangerous Alkali-Aggregate Reaction And Fire Resistance. Based On Laboratory Tests, Davidovits (1988b) Reported That Geopolymer Cement Can Harden Rapidly At Room Temperature And Gain The Compressive Strength In The Range Of 20 Mpa After Only 4 Hours At 20oc And About 70-100 Mpa After 28 Days. Comrie Et. Al., (1988) Conducted Tests On Geopolymer Mortars And Reported That Most Of The 28- Day Strength Was Gained During The First 2 Days Of Curing. Geopolymeric Cement Was Superior To Portland Cement In Terms Of Heat And Fire Resistance, As The Portland Cement Experienced A Rapid Deterioration In Compressive Strength At 300oc, Where The Geopolymeric Cements Were Stable Up To 600oc (Davidovits, 1988b; 1994b). 


\section{Preliminary Investigation}

Following parameters were fixed on the basis of experiments. Various authors $[13,14,15,16,17,18]$ conducted various trial mix tests.

\section{A. Fixed Parameter For Geopolymer Concrete}

- Replacement of cement in percentage by fly ash: $100 \%$.

- $\left(\mathrm{Na}_{2} \mathrm{SiO}_{3}\right)$ to $(\mathrm{NaOH})$ Solution: 2.5

- Solution to Fly ash ratio: 0.61 .

- Conc. Of Sodium Hydroxide 15M.

- Fineness of fly ash: $480 \mathrm{~m}^{2} / \mathrm{kg}$

\section{B. Variable Parameter For Geopolymer Concrete}

- Temperature: $60^{\circ} \mathrm{C}, 90^{\circ} \mathrm{C}, 120^{\circ} \mathrm{C}$

- Duration: 12 and 24 hours

\section{Properties Of Ingredients In Geopolymer.}

The ingredients of geopolymer concrete are process fly ash, sodium silicate, sodium hydroxide, coarse aggregate and fine aggregate. The aggregate having following properties as shown in the table.

Table II Properties of Coarse and Fine Aggregate

\begin{tabular}{|l|l|l|l|}
\hline Properties of material & CA-I & C A-II & SAND \\
\hline Type & Crushed & Crushed & Natural \\
\hline Shape & Cubical & Cubical & Spherical \\
\hline Maximum size & $20 \mathrm{~mm}$ & $12.5 \mathrm{~mm}$ & 4.75 \\
\hline Specific Gravity & 2.8 & 2.8 & 2.62 \\
\hline Crushing Value & $15 \%$ & $15 \%$ & -- \\
\hline
\end{tabular}

\section{Preparation Of Liquids}

The sodium hydroxide $(\mathrm{NaOH})$ solids were dissolved in water to make the solution. Mass of Sodium Hydroxide solids in a solution varied depending on the concentration of the solution expressed in terms of molar, M. Sodium Hydroxide solution with a concentration of $15 \mathrm{M}$ consisted of $15 \times 40=600$ grams of $\mathrm{NaOH}$ solids (in flake or pellet form) per litre of the solution, where 40 is the molecular weight of Sodium Hydroxide. Mass of Sodium Hydroxide solids was measured as 444 grams per $\mathrm{kg}$ of Sodium Hydroxide solution of $15 \mathrm{M}$ concentration. Similarly, the mass of Sodium Hydroxide solids per $\mathrm{kg}$ of the solution for $14 \mathrm{M}$ concentration was measured as 404 grams. The sodium silicate solution and the sodium hydroxide solution were mixed together at least one day prior to use to prepare the alkaline liquid. The day on which casting of the specimens, alkaline liquid was mixed together with the super plasticizer and the extra water to prepare the liquid component of the mixture.

\section{Determination Of Compressive Strength Of Geopolymer}

For oven cured and natural sunlight cured concrete, the strength of geopolymer concrete for various temperatures will be studied.

\section{E. Determination of Compressive strength at $60^{\circ} \mathrm{C}$}

The compressive strength is rises from $12 \mathrm{hrs}$ to $24 \mathrm{hrs}$. the compressive strength is considerably achieve but for the polymerization the temperature is not sufficient due to this the strength achieve is less. The Compressive strength of geopolymer concrete at $60^{\circ} \mathrm{C}$ as shown in following figure .

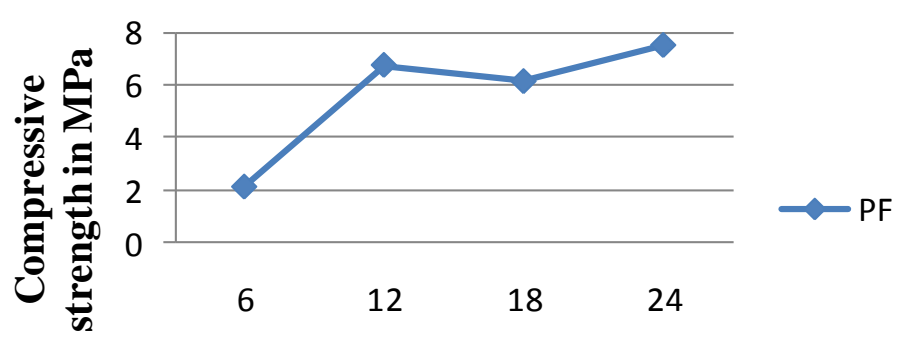

Duration in Hours 


\section{F. Determination Of Compressive Strength At $90{ }^{\circ} \mathrm{C}$}

For the study of effects of Alkali activated concrete with respect to temperature. The study shows that for the polymerisation the temperature is quite sufficient. The compressive strength at $90^{\circ} \mathrm{C}$ is as following figure.

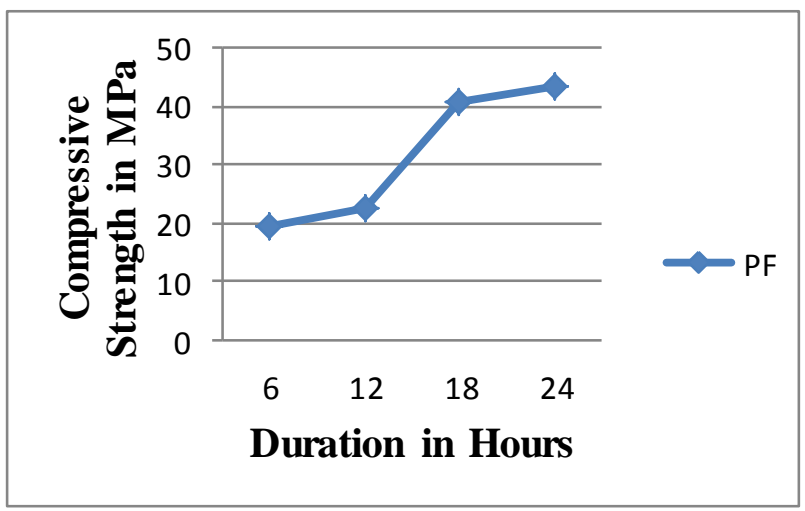

\section{G. Determination of Compressive strength at $120{ }^{\circ} \mathrm{C}$}

The study of alkali activated fly ash concrete the compressive strength is increases upto $18 \mathrm{hrs}$ for $120^{\circ}$ $\mathrm{C}$ oven temperature after that the compressive strength will not be increases considerably.

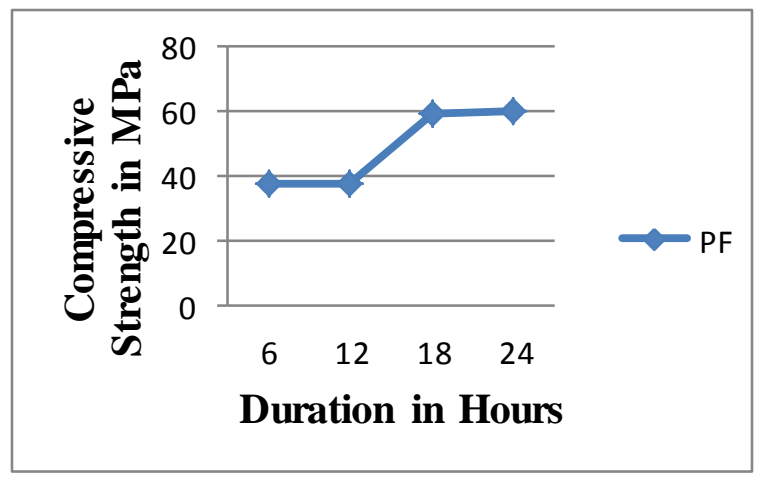

\section{H. Failure Pattern Of Fly Ash Based Geopolymer Concrete Cube In Compression Test.}

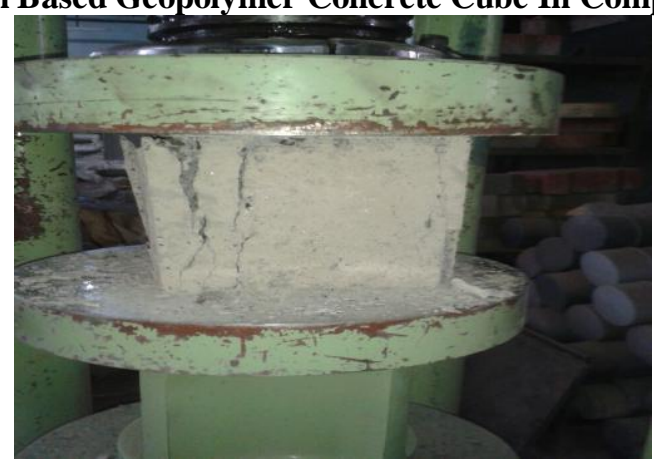

VI. Results And Discussion

1. Geopolymer concrete gives more strength than Normal concrete in minimum period of curing.

2. Higher curing temperature resulted in larger compressive strength of Geopolymer concrete, even though an increase in the curing temperature beyond $60 \mathrm{C}$ did not increase the compressive strength substantially.

3. Longer curing time improved the polymerization process resulting in higher compressive strength of Geopolymer concrete.

\section{References}

[1]. Atteshamuddin S. Sayyad and Subhash V. Patankar "Effect of Steel Fibres and Low Calcium Fly Ash on Mechanical and Elastic Properties of Geopolymer Concrete Composites", Volume 2013, Article ID 357563, 8 pages, Indian Journal of Materials Science.

[2]. B. V. Rangan "Mix Design and Production of Flyash based geopolymer Concrete" Indian Concrete Journal, in 2008. 
[3]. Binod Kumar; G. K. Tike; and P. K. Nanda "Evaluation of Properties of High-Volume Fly-Ash Concrete for Pavements" Journal of Materials in Civil Engineering, ASCE Vol. 19, No. 10, October 1-10-2007.

[4]. D. Hardjito and B. V. Rangan development and properties of low-calcium fly ash-based geopolymer concrete", 2005, Faculty of engineering curtin university of technology perth, Australia

[5]. D. Hardjito, Wallah, Sumajouw, and Rangan "Properties of Geopolymer Concrete with Fly Ash as Source Material: Effect of Mixture Composition", the Seventh International Conference on Recent Advances in Concrete Technology, 26-29 May, 2004, Las Vegas, USA.

[6]. Joseph davidovits and francisco al iaga "fabrication of stone objects, by geopolymeric synthesis, in the (peru)", 21st International Symposium for Archaeometry Brookhaven National Laboratory, , page 21, New-York, 1981

[7]. LUO Yu-ping, WANG Li-jiu "Research on non-steam-cured and non-fired fly-ash thermal insulating materials" J China Univ Mining \& Techno 11810 November 2007.

[8]. Monita Olivia, Hamid Nikraz R. "Properties of fly ash geopolymer concrete designed by Taguchi method" Journal of Elsevier, 3 Nov 2011.

[9]. Patel, Hossain, Bouzouba, Shehata, and Lachemi "Development of Statistical Models for Mixture Design of High-Volume Fly Ash Self-Consolidating Concrete" ACI Materials Journal, V. 101, No. 4, August 2004.

[10]. Prabir K. Sarker, Rashedul Haque , Karamchand V. Ramgolam "Fracture behaviour of heat cured fly ash based geopolymer concrete" Journal of Elsevier 11 August 2012.

[11]. Prinya Chindaprasirt, Ubolluk Rattanasak, Sompop Taebuanhuad "Role of microwave radiation in curing the fly ash geopolymer" Journal of Elsevier 10 January 2013.

[12]. Anuradha, Venktasubramani, Sreevidya, and Rangan "Modified guidelines for geopolymer concrete mix design using Indian Standards" Asian Journal of Civil Engineering, Vol 13, No 3, page 353-364, Year-2012.

[13]. Wallah and Rangan "low-calcium fly ash-based geopolymer concrete: long-term properties", Faculty of Engineering Curtin University of Technology Perth, Research Report GC 2,2006 Australia.

[14]. Subhash v. Patankar, Sanjay s. Jamkar, Yuwaraj m. Ghugal, "Effect of fly ash f ineness on workability and compressive strength of geopolymer concrete" The Indian Concrete Journal, 2013.

[15]. Subhash Patankar, Sanjay Jamkar, Yuwaraj, Ghugal, "Effect of Water-to-Geopolymer Binder Ratio on the Production of Fly ash Based Geopolymer Concrete" International Conference on Recent Trends in engineering \& Technology - 2013(ICRTET'2013) Organized By: SNJB's Late Sau. K. B. Jain College Of Engineering, Chandwad.

[16]. Subhash v. Patankar, Sanjay s. Jamkar, Yuwaraj m. Ghugal, "effect of water-to-geopolymer binder ratio on the production of fly ash based geopolymer concrete" international journal of advanced technology in civil engineering, issn: 2231 -5721, volume-2, issue-1, 2013.

[17]. Subhash V. Patankara, Yuwaraj M. Ghugal, Sanjay S. Jamkar "Selection of Suitable Quantity of Water, Degree and Duration of Heat Curing for Geopolymer Concrete Production” Proceedings of 3rd International Conference on Recent Trends in Engineering \& Technology (ICRTET'2014).

[18]. Subhash v. Patankar, yuwaraj m. Ghugal, sanjay s. Jamkar "effect of grading of fine aggregate on flow and compressive strength of geopolymer concrete" ukieri concrete congress in concrete construction. 